\section{Päivi Kososen vastine Kaisa Kurikalle}

Kaisa Kurikka arvosteli esseekokoelmani Elämisen taidosta. Esseitä modernin kirjallisuuden tunnosta (Tampere University Press, 2004) Avain-lehden viime numerossa (3-4/2005). Oli hienoa panna merkille arvostelun kriittis-sympaattinen ote, Kurikan tapa haastaa ajatteluani ja esittää kysymyksiä minua teilaamatta.

Haluaisin tässä vastata lyhyesti kahteen Kaisa Kurikan asettamaan kysymykseen. Ensimmäinen kysymyksistä koskee me-muotoa. Kurikka sanoo: "Vaikka ymmärrän me-muodon käytön retorisena keinona, en silti tiedä, kenestä Kosonen puhuu. Tarkoittaako hän meitä (nais)ihmisiä - Kososen itsensä käyttämä termi - vai esipuheessa nimettyjä meitä humanisteja, joille inhimillisen elämän kulun luonne on käynyt vieraaksi (ks. s. 10)? Keitä ovat me, joihin on äskettäin uudelleen herännyt halu lukea kunnon tarinaa alkuineen, keskikohtineen ja loppuineen (ks. s. 92)?"

Me-muoto ei ole pelkkää retoriikkaa, vaan olen sen avulla etsimässä ihmisiä kaltaisiani ihmisiä, sielunsukulaisia, omaa lukijayhteisöä, keskustelua tai paikkaa tai tilaa jossa voisin tuntea olevani kotona.
Sävyni on siis paatos: kirjoitan tutkijana ja naisihmisenä, joka etsii toisia, mutta kaltaisiaan tutkijoita ja (nais)ihmisiä. Vàlillä tunnen jopa olevani jonkinlainen viimeinen humanisti ja kysyn, onko täällä muita vai puhunko itsekseni. - On, joku on vastannut minulle.

Esseemuoto mahdollistaa tällaisen tutkimisen, oman lukijakunnan tunnustelun ja kuulostelun. Me-muodolla pyrin puhuttelemaan lukijoita, katson kuka vastaa ja miten. Tähän asti saamani palautteen perusteella osa lukijoista suostuu me-muotoon ja kokee tulleensa puhutelluksi, osaa taas me-muoto ärsyttää. Hyvillä kysymyksillään ja avoimen dialogisella asenteellaan Kaisa Kurikka näyttäisi kuuluvan jonnekin näiden kahden ääripään välimaastoon.

Toinen Kurikan kysymys koskee tekijän paluuta. Hän toteaa: "Lukija ja lukemisen nautinto ovat Kososen esseissä läsnä kaikkialla, mutta en lopulta pysty päättämään, onko Kosonen menossa kohti jotain uudenlaista tapaa käsittää tekijän suhde teokseen ja lukijaan sekä ylipäätään tulkintaan, vai onko hän palaamassa vanhaan. Vai onko niin, että juuri Kososen kirjoitusten esseemuoto sallii nostalgisen tarpeen herättää jo kertaalleen tapettu Tekijä uudelleen henkiin?" (s. 135.)

Kysymys tekijästä on hankala ja varmaan elämäntehtäväni mittainen - ainakin sikäli kuin sitä kautta tullaan kysymykseen "ihmisestä" ja "inhimillisestä tekijästä", "inhimillisestä toiminnasta": siis kirjallisuutta ja merkityksellistymistä ympäröivästä elämisestä, tuntemisesta, 
oitan tutkijana toisia, mutta is)ihmisiä. Vànkinlainen vii$n$, onko täällä ni. - On, joku istaa tällaisen unnan tunnus-muodolla pya, katson kuka ti saamani paijoista suostuu eensa puhutelársyttää. Hyvilnen dialogisella näyttäisi kuuhıden ääripään

nys koskee te: "Lukija ja luososen esseissä lopulta pysty n menossa kohkäsittää tekijän sekä ylipäätään alaamassa vanjuuri Kososen allii nostalgisen leen tapettu $\mathrm{Te}$ s. 135.)

hankala ja varnittainen - aiitta tullaan ky"inhimillisestä toiminnasta": tyksellistymistä tuntemisesta, kirjoittamisesta, muistelemisesta, lukemisesta, ajattelemisesta, kuvittelemisesta. En ole pitkään aikaan tuntenut olevani kotona vallitsevan kirjallisuudentutkimuksen (olipa se sitten ukon- tai akanvirtaa) nominalistis-hierarkkisissa teorioissa, niiden käsitteissä ja lokeroissa, mutten ole valitettavasti myöskään kyennyt muotoilemaan uutta ja koherenttia teoriaa ymmärrykseni pohjalta. Ounastelen, että nykyinen kirjallisuus- ja tekijäkäsitys tulevat radikaalisti muuttumaan eli tekijä ja lukija palaavat, mutta tämän paluun pääteoretisoijat eivät ehkä ole meitä kirjallisuudentutkijoita - tai ainakaan pelkästään. Wellekin ja Warrenin "virhepäärelmät" on siitä huolimatta otettava uudestaan agendalle - uudelta pohjalta ja myös yhdessä toisten oppialojen kysymyksenasettelujen kanssa.

\section{Päivi Kosonen}

\section{Inszenierung of Fremde in contemporary German immigrant literature}

This article discusses the works of immigrant authors in the Germanspeaking countries. Their literature was first defined as Ausländerliteratur which is out-dated today since by now many authors have spent most of their life in Germany. Equally misleading is Minoritätenliteratur which puts the emphasis merely on the political situation of immigrant authors. More successful are Migrationsliteratur and interkulturelle Literatur which have gained popularity in the recent discussion. The academic discussion about immigrant literature has undergone a change from the 1980 s until today. The first attempts involved relating immigrant literature to German literature in general, but this approach tended to ignore not only the cross-culturality but also the often innovative aesthetic qualities of these fictional works.

The theoretical background of this article is in Lothar Krappmann's sociological definition of identity as a space of interaction which allows the personal identity to come into being. Krappmann's view of identity is further elaborated by Ortrud Gutjahr's discussion about the importance of Fremde for the development of personal identity. The descriptions of familiarity and unfamiliarity in the works of immigrant 